\title{
Arbuscular mycorrhizal fungi on the biomass and nutrition of Urochloa decumbens at different soil densities
}

\author{
Luciane Reis Sales(1), Geanderson Nascimento da Silva(2), \\ Raphael Henrique da Silva Siqueira ${ }^{(3)}$, Marco Aurélio Carbone Carneiro(1) and Valdemar Faquin ${ }^{(1)}$
}

\begin{abstract}
(1)Universidade Federal de Lavras, Departamento de Ciência do Solo, Campus Universitário, Caixa Postal 3037, CEP 37200-000 Lavras, MG, Brazil. E-mail: luciane_lavras@yahoo.com.br, marcocarbone@dcs.ufla.br, vafaquin@dcs.ufla.br (2)Instituto Federal de Educação, Ciência e Tecnologia do Sertão Pernambucano, Campus Petrolina, BR 407, Km 8, Jardim São Paulo, CEP 56314-520 Petrolina, PE, Brazil. E-mail: gean.tecnologo@hotmail.com ${ }^{(3)}$ Universidade Federal de Roraima, Campus Cauamé, Centro de Ciências Agrárias, BR 174, Km 12, Monte Cristo, CEP 69300-000 Boa Vista, RR, Brazil. E-mail: raphael_manejosolo@hotmail.com
\end{abstract}

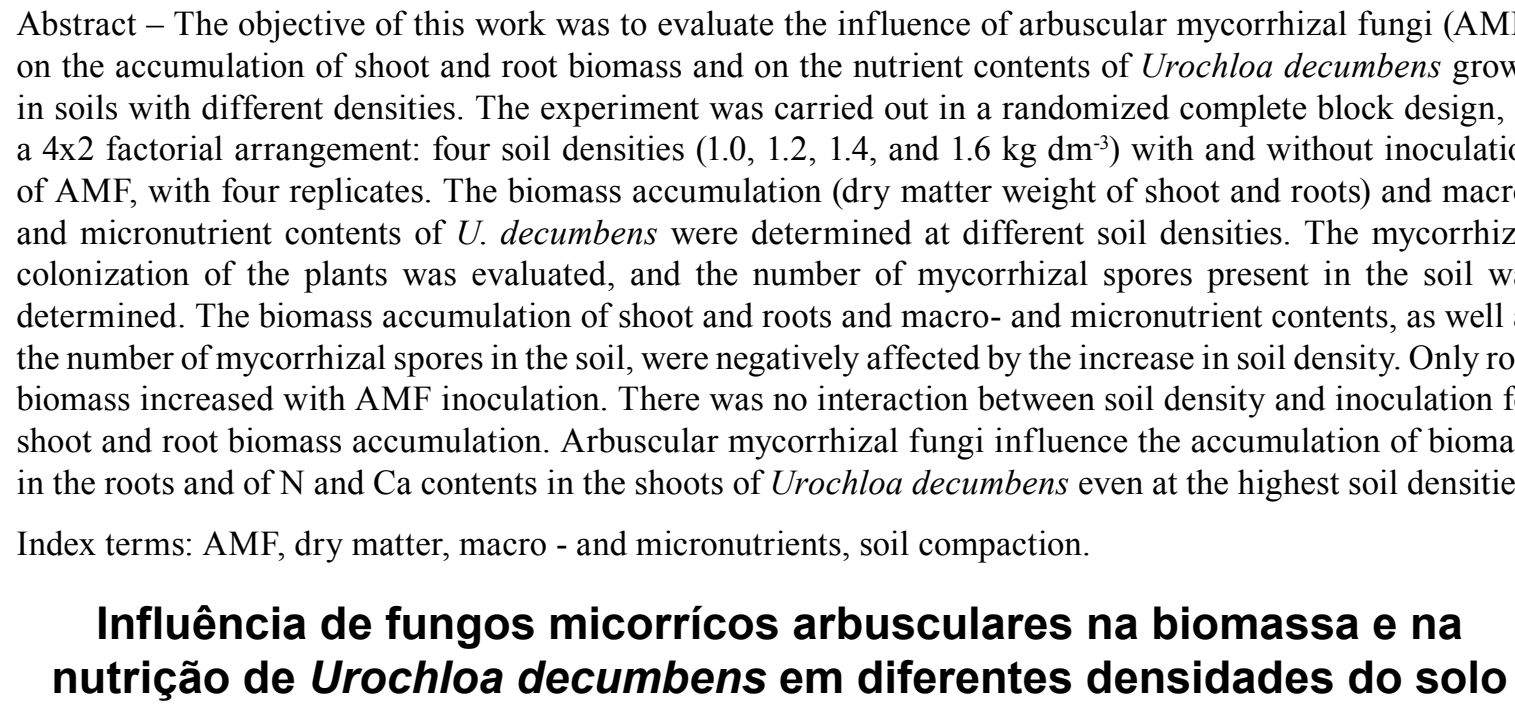

Resumo - O objetivo deste trabalho foi avaliar a influência de fungos micorrízicos arbusculares (FMA) na acumulação de biomassa da parte aérea e da raiz e nos teores de nutrientes de Urochloa decumbens cultivada em solos com diferentes densidades. O delineamento experimental foi em blocos ao acaso, em arranjo fatorial 4x2: quatro densidades do solo $\left(1,0,1,2,1,4\right.$ e $\left.1,6 \mathrm{~kg} \mathrm{dm}^{-3}\right)$ com e sem inoculação de FMA, com quatro repetições. Determinaram-se a acumulação de biomassa (massa de matéria seca da parte aérea e da raiz) e os teores de macro e micronutrientes em $U$. decumbens, nas diferentes densidades do solo. Avaliou-se a colonização micorrízica das plantas, e determinou-se o número de esporos micorrízicos presentes no solo. A acumulação de biomassa da parte aérea e da raiz e o conteúdo de macro e micronutrientes, bem como o número de esporos micorrízicos no solo, foram afetados negativamente pelo aumento na densidade do solo. Apenas a biomassa de raízes apresentou incremento com a inoculação de FMA. Não houve interação da densidade do solo e da inoculação na acumulação de biomassa na parte aérea e na raiz. Os fungos micorrízicos arbusculares influenciam a acumulação de biomassa nas raízes e de $\mathrm{N}$ e Ca na parte aérea de Urochloa decumbens mesmo nas densidades mais altas.

Termos para indexação: FMA, matéria seca, macro e micronutrientes, compactação do solo.

\section{Introduction}

The conversion of large areas of natural vegetation for animal production is one of the major causes of degradation in rural areas in Brazil. According to Macedo et al. (2013), more than $70 \%$ of the 117 million hectares of cultivated pastures used for livestock grazing are degraded up to an extent. The compaction promoted by the compression of unsaturated soil affects the development of the root system and the consequent absorption of water and macro- and micronutrients (Miransari et al., 2009b; Castagnara et al., 2013; Farias et al., 2013). Soil compaction can also increase physical 
resistance to root penetration, decrease porosity, limit pore continuity and soil aeration, and impair water infiltration and hydraulic conductivity (Valicheski et al., 2012; Farias et al., 2013).

Different management practices, such as subsoiling and cover plants, are used to break down compacted soil layers. While subsoiling has high operational costs, the use of hedge plants with a vigorous root system is a sustainable alternative and can mitigate, at relatively low costs, the negative effects of the inadequate management of soil structure (Valicheski et al., 2012). Among the used cover plants, Urochloa decumbens (Stapf) R.D.Webster (Syn. Brachiaria decumbens Stapf) stands out due to its deep root system that is resistant to drought and to its very good response to mycorrhizal colonization with arbuscular mycorrhizal fungi (AMF), according to Carneiro et al. (1999).

AMF act indirectly on the recovery process of compacted areas, via the effects on soil properties resulting from their extensive influences on plant nutrition, growth, and adaptation to the biotic and abiotic stresses of agroecosystems (Gomide et al., 2009; Miransari et al., 2009b). These fungi work together with plant roots through extraradicular hyphae that increase the contact area of the soil and, consequently, the absorption of phosphorus and other nutrients, providing a greater growth of the plants (Carneiro et al., 2004). In addition, AMF act to improve soil structure by producing glomalin, a glycoprotein that is a component of the hyphae cell wall and is insoluble in water, acting as a cementing agent for soil particles, besides contributing to carbon stock in the soil (Treseder et al., 2007). AMF can also encourage greater plant growth and improve plant nutritional status under conditions of soil compaction (Miransari et al., 2007, 2009a, 2009b).

The effects of soil compaction on the concentration of primary macronutrients were evaluated in the leaves of the Urochloa brizantha Piatã and Panicum maximum Mombaça grass cultivars in a greenhouse (Cabral et al., 2012). The authors found that, during plant growth, soil compaction interferes with nitrogen, phosphorus, and potassium uptake; however, the effects were different for these nutrients: nitrogen, for example, was the macronutrient most limited by compaction, while phosphorus absorption was greater at higher soil densities due to increased soil compaction. However, the effect of AMF was not assessed in that research and is still little studied in Brazilian soil conditions.
The objective of this work was to evaluate the influence of arbuscular mycorrhizal fungi on the accumulation of shoot and root biomass and on the nutrient contents of Urochloa decumbens grown in soils with different densities.

\section{Materials and Methods}

The experiments were conducted in a heated greenhouse at the Department of Soil Science of Universidade Federal de Lavras, located in Lavras, in the state of Minas Gerais, Brazil. During the experiment, the average temperature of the greenhouse was $27^{\circ} \mathrm{C}$ and the mean humidity was $67 \%$.

The soil used was collected from the subsurface horizon of a Latossolo Vermelho distroférrico, i.e., a Typic Haplorthox, of clayey texture (Santos et al., 2013), which was air-dried, sieved through a 2-mm mesh, and subjected to the chemical analysis. The soil presented the following chemical properties: $\mathrm{pH}\left(\mathrm{H}_{2} \mathrm{O}\right)$ 5.5, 0.01 $\mathrm{cmol}_{\mathrm{c}} \mathrm{dm}^{-3} \mathrm{Al}^{3+}, 0.4 \mathrm{cmol}_{\mathrm{c}} \mathrm{dm}^{-3} \mathrm{Ca}^{2+}, 0.1 \mathrm{cmol}_{\mathrm{c}} \mathrm{dm}^{-3}$ $\mathrm{Mg}^{2+}, 2.08 \mathrm{cmol}_{\mathrm{c}} \mathrm{dm}^{-3} \mathrm{H}+\mathrm{Al}, 2.0 \mathrm{cmol}_{\mathrm{c}} \mathrm{dm}^{-3} \mathrm{~K}^{+}, 0.01 \mathrm{mg}$ $\mathrm{dm}^{-3} \mathrm{P}$ (Mehlich-1), effective cation exchange capacity of $0.52 \mathrm{cmol}_{\mathrm{c}} \mathrm{dm}^{-3}$, base saturation of $20 \%$, and $15.2 \mathrm{~g}$ $\mathrm{kg}^{-1}$ soil organic matter. Soil liming was performed to raise base saturation to $60 \%$. Then, soil was incubated for 25 days in the humidity established as field capacity, i.e., $60 \%$ of the total pore volume (TPV).

The experiment was carried out in a randomized complete block design, set in a $4 \times 2$ factorial arrangement: four degrees of soil compaction (densities of $1.0,1.2,1.4$, and $1.6 \mathrm{~kg} \mathrm{dm}^{-3}$ ) and inoculation or not with AMF, with four replicates.

The experimental plots consisted of pots (vessels) formed by the overlapping of two rigid PVC rings. These pots had a diameter of $23 \mathrm{~cm}$, with a $10-\mathrm{cm}$ PVC ring on the top and a $20-\mathrm{cm}$ one on the bottom; the two rings were fixed with duct tape. The lower ring was filled with uncompacted soil at a density of 1.08 $\mathrm{kg} \mathrm{dm}{ }^{-3}$, while the upper ring was filled with 4.48, $4.98,5.82$, and $6.64 \mathrm{~kg}$ soil, which, afterwards, was subjected to the different degrees of soil density.

A hydraulic press was used to compact the soil surface layer $(0-10 \mathrm{~cm})$ in the vessels, and soil moisture was corrected to $15 \%$ field capacity. To avoid the deformation or rupture of the upper ring of the PVC vessel by soil compression, an additional metal ring ( $3 / 8$ " steel plate) of equal internal dimensions 
was placed around the PVC. Mean densities were determined based on the ring volume of the soil mass, calculated by the formula: soil densities $(1.08,1.20$, 1.40 , and $\left.1.60 \mathrm{~kg} \mathrm{dm}^{-3}\right) \mathrm{x}$ upper ring volume $\left(4.15 \mathrm{dm}^{-3}\right)$ $=$ soil mass. The soil masses obtained for the different densities were used to fill the upper ring: $4.48 \mathrm{~kg}$ for $1.08 \mathrm{~kg} \mathrm{dm}^{-3}, 4.98 \mathrm{~kg}$ for $1.20 \mathrm{~kg} \mathrm{dm}^{-3}, 5.82 \mathrm{~kg}$ for 1.40 $\mathrm{kg} \mathrm{dm}{ }^{-3}$, and $6.64 \mathrm{~kg}$ for $1.60 \mathrm{~kg} \mathrm{dm}^{-3}$. Initial density was established with soil sieved at $4 \mathrm{~mm}$, which was considered uncompacted.

Before compaction, soil was fertilized with the following doses of macro- and micronutrients, according to Malavolta (1980): $300 \mathrm{mg} \mathrm{kg}^{-1} \mathrm{~K}, 300 \mathrm{mg}$ $\mathrm{kg}^{-1} \mathrm{~N}, 100 \mathrm{mg} \mathrm{kg}^{-1} \mathrm{P}, 0.5 \mathrm{mg} \mathrm{kg}^{-1} \mathrm{~B}, 1.5 \mathrm{mg} \mathrm{kg}^{-1} \mathrm{Cu}$, $1.0 \mathrm{mg} \mathrm{kg}^{-1} \mathrm{Mo}$, and $5.0 \mathrm{mg} \mathrm{kg}^{-1} \mathrm{Zn}$. The upper part of the vessels received $60 \%$ and the lower part $40 \%$ of the applied dose. The sources used for fertilization were: potassium nitrate $\left(\mathrm{KNO}_{3}\right)$, ammonium nitrate $\left(\mathrm{NH}_{4} \mathrm{NO}_{3}\right)$, monoammonium phosphate (MAP), boric acid $\left(\mathrm{H}_{3} \mathrm{BO}_{3}\right)$, zinc sulfate $\left(\mathrm{ZnSO}_{4} \cdot 7 \mathrm{H}_{2} \mathrm{O}\right)$, copper sulfate $\left(\mathrm{CuSO}_{4}\right)$, and ammonium molybdate $\left[\left(\mathrm{NH}_{4}\right)_{6} \mathrm{Mo}_{7} \mathrm{O}_{24}\right]$.

Seeds of $U$. decumbens were treated with sulphuric acid (1\%) to break dormancy, washed, and stored in a refrigerator at $20^{\circ} \mathrm{C}$. The superficial layer of the soil was scarified for sowing, followed by the addition of $15 \mathrm{~mL}$ soil inoculum containing 150 spores of Claroideoglomus etunicatum (W.N. Becker \& Gerd.) C. Walker \& A. Schüßler and Acaulospora morrowiae Spain \& N.C. Schenck in the 1:10 ratio, hyphae, and colonized roots, which also act as propagules of AMF. Ten seeds were sown in each experimental pot, and, after germination, thinning was done to allow the growth of three plants. Irrigation was performed daily with deionized water, aiming to maintain soil moisture near field capacity, i.e., $60 \%$ TPV.

At 45 days after sowing, plant shoot and roots were cut, washed in distilled water to obtain the fresh matter weight (gram per pot) of shoot and roots, and separated to determine the dry matter weight (gram per pot) of shoot and roots; the material was dried in an oven at $65-70^{\circ} \mathrm{C}$ until reaching constant weight. The same plant material was then ground in a Wiley-type mill, homogenized, and sampled for the determination of macro- and micronutrient contents, as described in Malavolta (1997). The nutrient content in the shoot biomass, in each experimental plot, was obtained by correlating soil density with the dry matter weight of the plant shoot.
Soil samples of $500 \mathrm{~g}$ each were removed and sieved in a 2-mm mesh. Root fragments of $\pm 1 \mathrm{~g}$ were removed and stored in $70 \%$ alcohol for evaluation of mycorrhizal colonization. AMF spores were then extracted from this same soil sample to determine the number of spores present.

The thin roots were clarified and colored according to the method of Koske \& Gemma (1989) and Grace \& Stribley (1991), placed on slides with glycerin, and observed under an optical microscope, in order to quantify mycorrhizal colonization in about 130 root segments, each with 1-mm length, which were randomly sampled. AMF spore extraction was performed as in Gerdmann \& Nicolson (1963), followed by centrifugations in water and $45 \%$ sucrose, to determine the number of spores per $50 \mathrm{~mL}$ soil.

Data were subjected to the analysis of variance, and, when significant, differences were tested with the regression analysis and Tukey's test, at 5\% probability, using the Sisvar software (Ferreira, 2014).

\section{Results and Discussion}

The biomass accumulation (dry matter) of shoot and roots was affected by soil density. A decreasing linear trend was observed for the dry biomass of shoot (103.26 to $42.40 \mathrm{~g}$ per pot) and roots (157.60 to $57.76 \mathrm{~g}$ per pot), showing the negative effect of increased soil density on the development of $U$. decumbens (Figure 1). However, only root dry biomass accumulation was affected by AMF soil inoculation, and there was no interaction between the factors soil density and AMF inoculation on shoot and root biomass accumulation.

Inoculation with AMF in the soil in which $U$. decumbens was grown did not alleviate the effects of soil compaction on shoot biomass accumulation. Despite the decrease in root dry matter under soil compaction, the plants that received AMF soil inoculation showed an increase of $31 \%$ in root biomass in relation to those without inoculation (Figure 2).

The greater growth of the root system may have been promoted by AMF, either via physiological changes of roots or by a greater translocation of nutrients and water from the fungus to the plant. The low accumulation of shoot dry biomass under conditions of high soil compaction has also been reported for rice (Oryza sativa L.) (Medeiros et al., 2005) and U. brizantha (Lima et al., 2015), which is in alignment with the results of the present study. Thorne et al. (2013) tested

Pesq. agropec. bras., Brasília, v.53, n.8, p.943-951, Aug. 2018 DOI: 10.1590/S0100-204X2018000800009 
the performance of arbuscular mycorrhizal fungi in three grass species under different compaction degrees and found significant effects on biomass accumulation only for the root system.

The mean increase of root dry matter per pot was $30.54 \mathrm{~g}$ for the treatments with AMF. This value may seem low, but the one estimated per hectare was 6,305 $\mathrm{kg} \mathrm{ha}^{-1}$, much below those of the treatments subjected to inoculation (Figure 2). This may have contributed to the increase in organic carbon in the soil and, consequently, to the reduction in soil physical degradation.

Soil density had a significant effect on the contents of $\mathrm{N}, \mathrm{P}, \mathrm{Ca}, \mathrm{Mg}$, and $\mathrm{S}$. The inoculation of soil with AMF only affected the contents of $\mathrm{N}$ and $\mathrm{Ca}$, and there was no interaction of the factors soil density and AMF inoculation for these variables (Table 1).

The contents of the $\mathrm{N}, \mathrm{P}, \mathrm{Mg}$, and $\mathrm{S}$ macronutrients in shoot dry biomass decreased with increasing soil
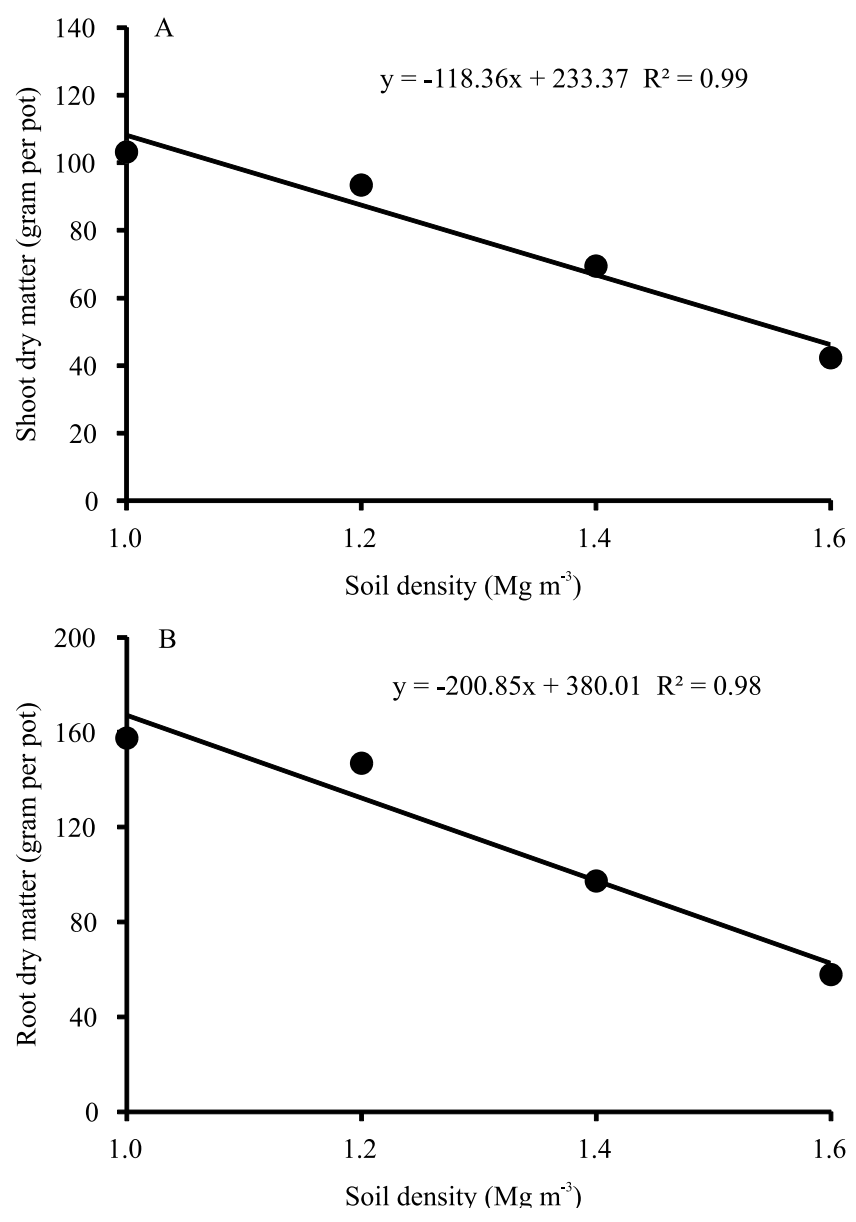

Figure 1. Shoot dry matter (A) and root dry matter (B) of Urochloa decumbens grown at different degrees of soil density. density (Figure 3). The reduction in $\mathrm{N}$ uptake from 2.54 to $1.40 \mathrm{~g}$ per pot with increased soil compaction may be related to the increase in the denitrification rate and to the lower availability of oxygen to the plant roots due to the change in the $\mathrm{NH}^{4+} / \mathrm{NO}_{3}{ }^{-}$ratio, affecting $\mathrm{N}$ content (Miransari et al., 2009a). The soil density of $1.6 \mathrm{~kg} \mathrm{dm}^{-3}$ reduced the contents of $\mathrm{P}, \mathrm{Mg}$, and $\mathrm{S}$ in 30,51 , and $40 \%$, respectively, in comparison with the soil density of $1.0 \mathrm{~kg} \mathrm{dm}^{-3}$. Increased soil compaction favors the decrease in the diffusive flux and the increase in phosphate adsorption due to the greater contact with the surface of the solid fraction of the soil caused by the breaking of aggregates in compacted soils (Ribeiro et al., 2010; Souza et al., 2012); therefore, the availability of $P$ and plant uptake
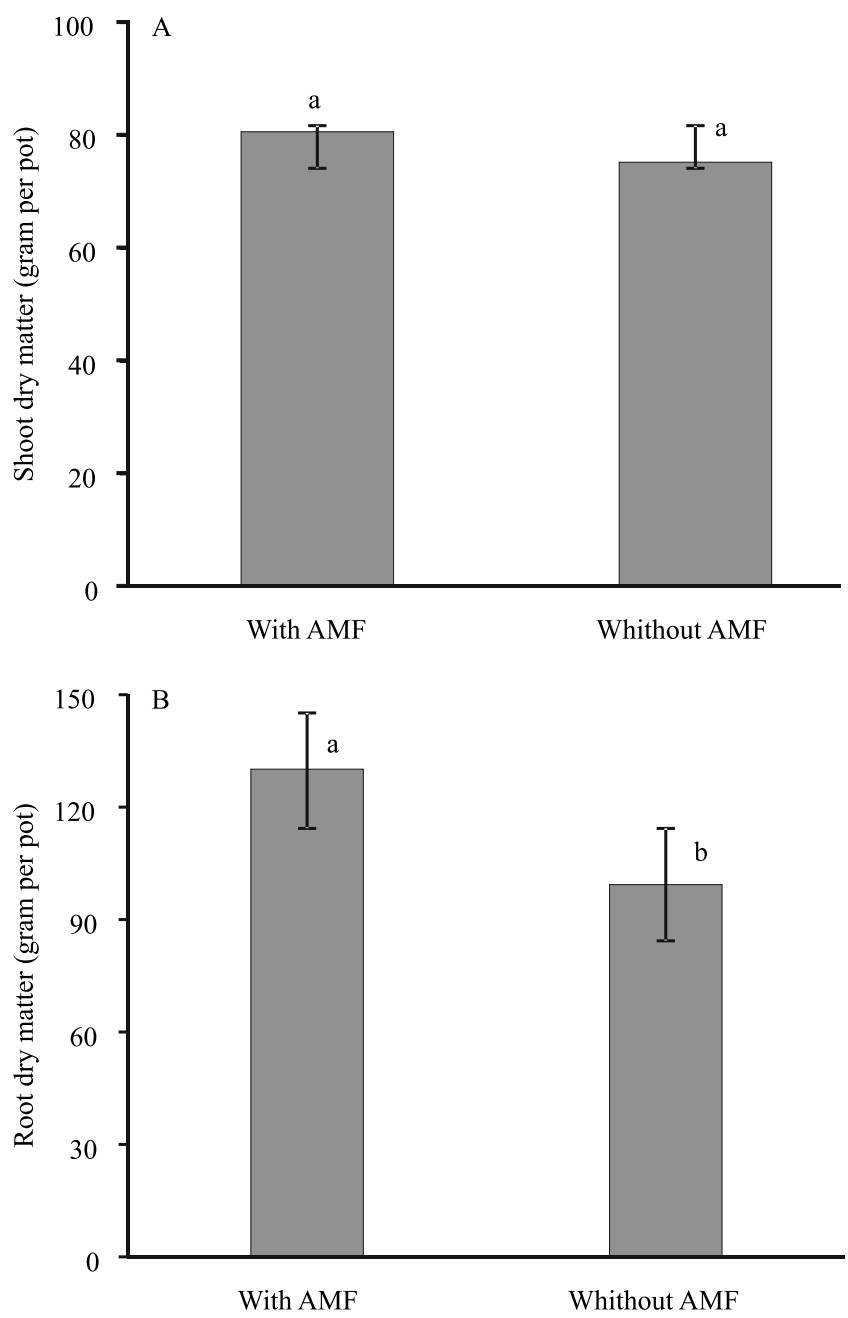

Figure 2. Shoot dry matter (A) and root dry matter (B) of Urochloa decumbens with and without inoculation of arbuscular mycorrhizal fungi (AMF). 
Table 1. Contents of the nitrogen, phosphorus, potassium, calcium, magnesium, and sulfur macronutrients of Urochloa decumbens, with and without the inoculation of the arbuscular mycorrhizal fungi (AMF) Claroideoglomus etunicatum and Acaulospora morrowiae ${ }^{(1)}$.

\begin{tabular}{|c|c|c|c|c|c|}
\hline Treatment & $\mathrm{N}$ & $\mathrm{P}$ & $\mathrm{Ca}$ & $\mathrm{Mg}$ & $\mathrm{S}$ \\
\hline & & - & am per & --- & $-\cdots$ \\
\hline With AMF & $2.20 \mathrm{a}$ & $0.10 \mathrm{a}$ & $0.26 \mathrm{a}$ & $0.27 \mathrm{a}$ & $0.12 \mathrm{a}$ \\
\hline Without AMF & $1.97 \mathrm{~b}$ & $0.11 \mathrm{a}$ & $0.21 \mathrm{~b}$ & $0.24 \mathrm{a}$ & $0.13 \mathrm{a}$ \\
\hline CV (\%) & 11.05 & 15.60 & 19.70 & 14.81 & 13.43 \\
\hline
\end{tabular}

(1)Means followed by equal letters, in the columns, do not differ by Tukey's test, at $5 \%$ probability. $\mathrm{CV}$, coefficient of variation.
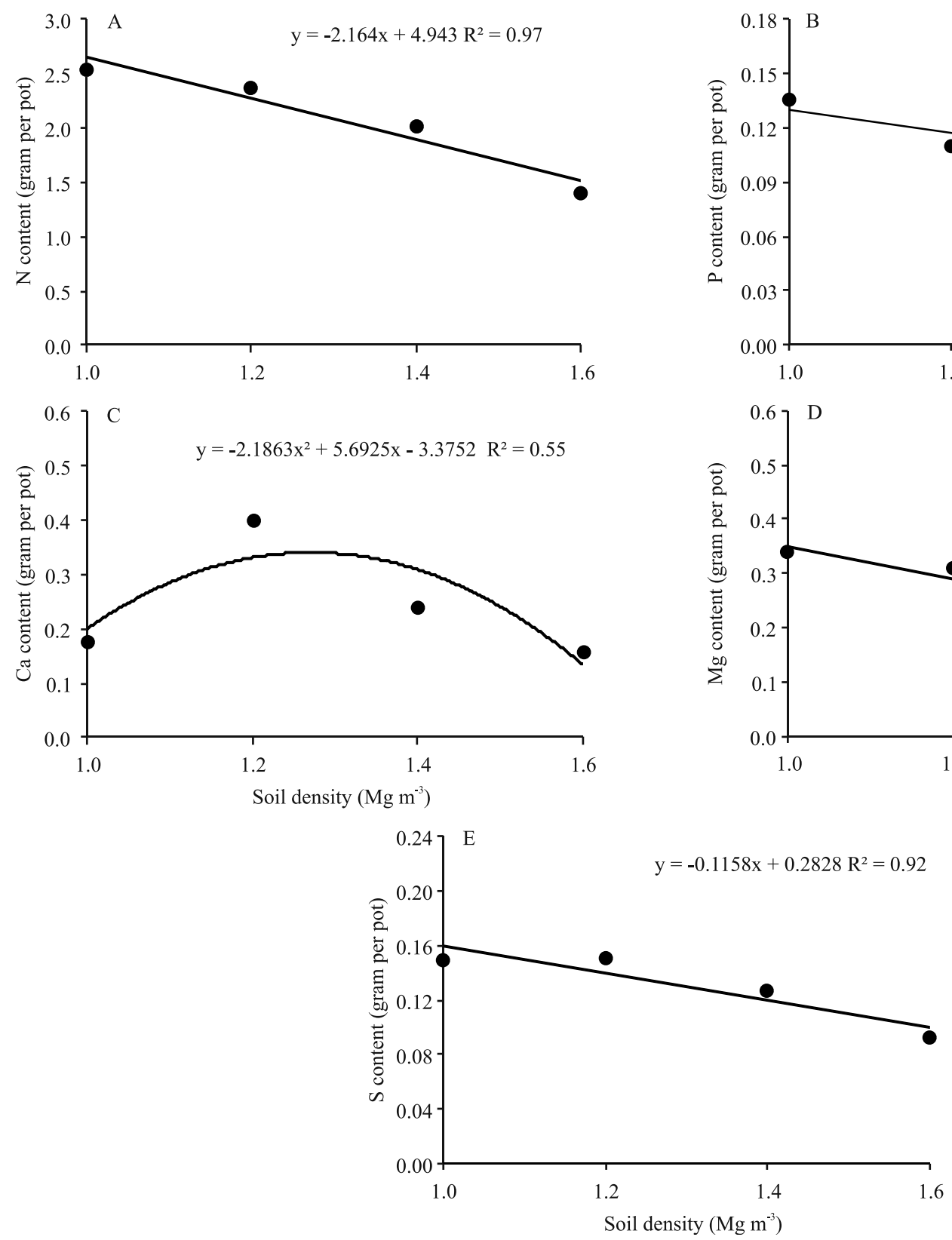

Figure 3. Nitrogen, phosphorus, calcium, magnesium, and sulfur contents of Urochloa decumbens grown at different degrees of soil density. are reduced, resulting in a lower accumulation of the $\mathrm{N}, \mathrm{P}, \mathrm{Mg}$, and $\mathrm{S}$ contents, as density increases, can also be related to the greater mobility of these nutrients in uncompacted soils.

Regarding non-mycorrhizal plants, the inoculation with AMF promoted a greater accumulation of $\mathrm{N}$. However, this result was not followed by an increase in $\mathrm{P}$ content (Table 1). As $\mathrm{N}$ is one of the most demanded nutrients by plants, it may constitute from 2 to $5 \%$ of
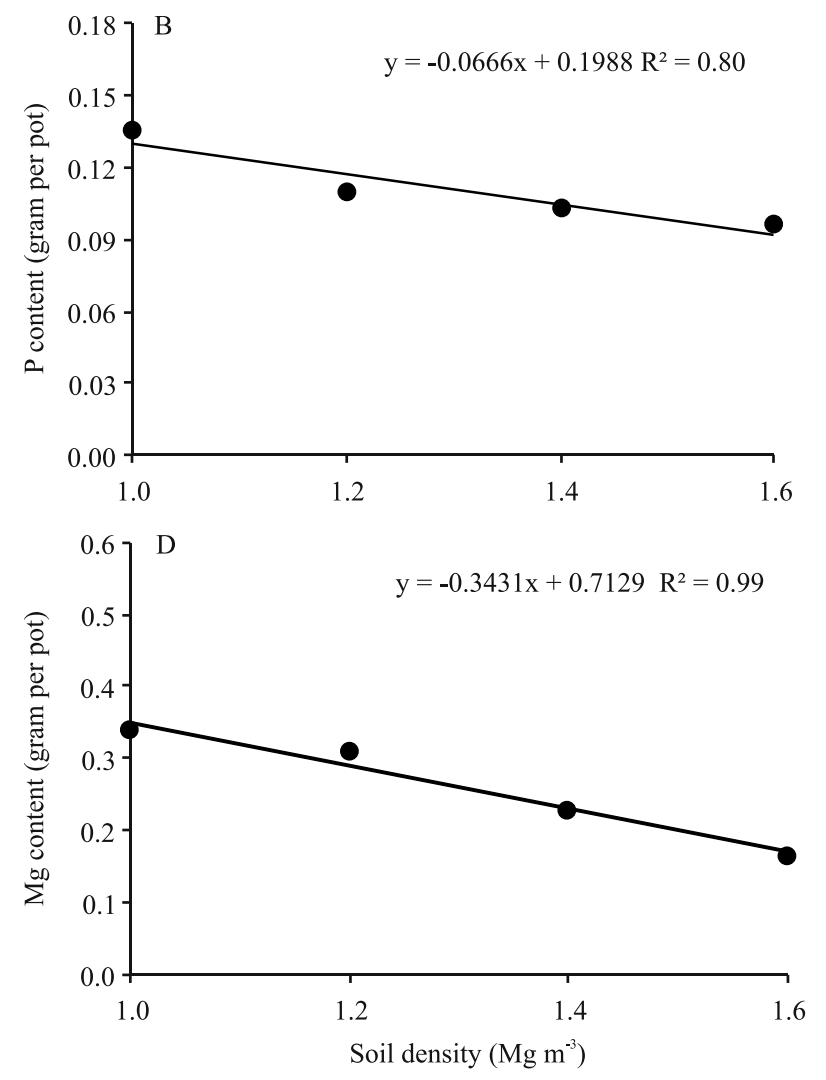

6 this nutrient. Moreover, the tendency of reduction in 
plant dry matter, which has a direct relationship with plant growth. This may explain the higher root dry matter values of mycorrhized plants due to the greater $\mathrm{N}$ absorption by mycorrhizal hyphae, associated with their roots. An opposite effect on $\mathrm{P}$ content was reported for wheat (Triticum aestivum L.) crop grown on soil inoculated with arbuscular mycorrhizae inoculated at different compaction degrees (Miransari et al., 2009a).

In the present study, the content of $\mathrm{Ca}$ in the biomass was influenced by AMF inoculation and was 19.2\% higher in mycorrhized plants, compared with the nonmycorrhized ones (Table 1). Ca has low mobility in the soil, and the increase in the absorption area promoted by AMF may have allowed this nutrient to be better absorbed, i.e., $0.26 \mathrm{~g}$ per pot with AMF and $0.21 \mathrm{~g}$ per pot without AMF.

There was no effect of the soil densities $\mathrm{x}$ AMF interaction on the micronutrient contents of the evaluated $U$. decumbens plants (Table 2). However, the contents of $\mathrm{Cu}, \mathrm{Fe}, \mathrm{Mn}$, and $\mathrm{Zn}$ were significantly affected by soil density and of Mn by AMF inoculation. The results for the contents of $\mathrm{Cu}, \mathrm{Fe}$, and $\mathrm{Mn}$ fitted to the linear regression model of inverse order, while those for $\mathrm{Zn}$ best fitted to the quadratic model (Figure 4).

Both micro- and macronutrients showed lower contents in the shoot as the soil density increased

Table 2. Summary of the variance analysis and averages for the copper, iron, manganese, and zinc contents of Urochloa decumbens at different degrees of soil density (SD), with and without arbuscular mycorrhizal fungi (AMF) inoculation and interactions ${ }^{(1)}$.

\begin{tabular}{lcccc}
\hline \multirow{2}{*}{$\begin{array}{l}\text { Source of } \\
\text { variation }\end{array}$} & $\mathrm{Cu}$ & $\mathrm{Fe}$ & $\mathrm{Mn}$ & $\mathrm{Zn}$ \\
\cline { 2 - 5 } $\mathrm{SD}$ & $0.1420^{* *}$ & $16.360^{* *}$ & $30.5060^{* *}$ & $5.3859^{* *}$ \\
$\mathrm{AMF}$ & $0.0306^{\mathrm{ns}}$ & $1.4706^{\mathrm{ns}}$ & $5.3219^{* *}$ & $0.3465^{\mathrm{ns}}$ \\
$\mathrm{SD} \times \mathrm{AMF}$ & $0.0194^{\mathrm{ns}}$ & $0.2342^{\mathrm{ns}}$ & $1.0541^{\mathrm{ns}}$ & $0.1220^{\mathrm{ns}}$ \\
\hline & $----------------($ milligram per pot)----------------- & & \\
With AMF & $0.58 \mathrm{a}$ & $4.14 \mathrm{a}$ & $7.46 \mathrm{a}$ & $3.75 \mathrm{a}$ \\
Without AMF & $0.52 \mathrm{a}$ & $3.71 \mathrm{a}$ & $6.65 \mathrm{~b}$ & $3.55 \mathrm{a}$ \\
\hline CV (\%) & 15.92 & 16.32 & 12.63 & 11.78 \\
\hline
\end{tabular}

${ }^{(1)}$ Means followed by equal letters, in the columns, do not differ by Tukey's test, at $5 \%$ probability. $* *$ and $*$ Significant at 1 and $5 \%$ probability,

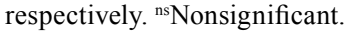
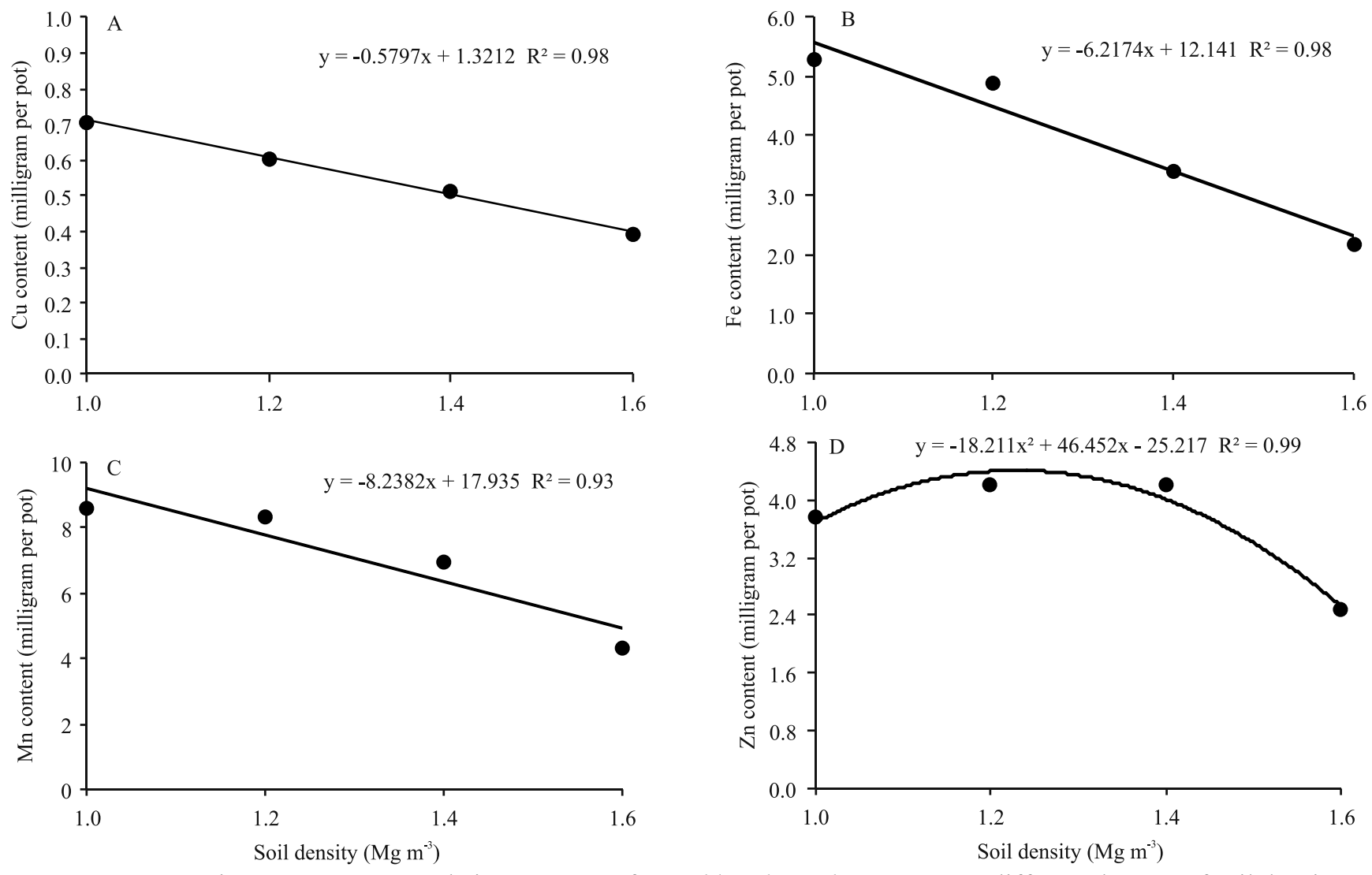

Figure 4. Copper, iron, manganese, and zinc contents of Urochloa decumbens grown at different degrees of soil density. 
(Figures 3 and 4). The $\mathrm{Cu}, \mathrm{Fe}$, and $\mathrm{Mn}$ contents reduced in 44, 59, and 49\%, respectively, in the shoot at the highest soil density of $1.60 \mathrm{~kg} \mathrm{dm}^{-3}$, in comparison with the lowest one. The reductions in the accumulation of micronutrients from the lowest to the highest soil density were within the range found for macronutrients. Regarding Zn content, the maximum value was $4.21 \mathrm{mg}$ per pot at the soil density of $1.2 \mathrm{~kg}$ $\mathrm{dm}^{-3}$, and the lowest was $2.48 \mathrm{mg}$ per pot at the highest soil density, indicating a reduction in $\mathrm{Zn}$ accumulation in more compacted soils.

In relation to the effect of AMF on micronutrient contents, no significant differences were found between plants with or without AMF soil inoculation (Table 2). The exception was for Mn content, which significantly increased from $6.65 \mathrm{mg}$ per pot without AMF to 7.46 mg per pot with AMF. Miransari et al. (2009b) found a higher Mn uptake by corn (Zea mays L.) plants when inoculated with arbuscular mycorrhizal fungi.

Soil density had no effect on the mycorrhizal colonization of plant roots. However, the soil density $x$ AMF interaction affected the percentage of colonization and spore number (Table 3). Mycorrhizal colonization was fitted to the quadratic model when tested for the soil density $\mathrm{x}$ AMF interaction, which had significant coefficients for the treatments with AMF (Figure 5). It should be noted that, for spore number, by unfolding the degrees of freedom, the coefficients were significant only for the treatments without AMF.

Mycorrhizal colonization did not interfere with soil density; however, when comparing the treatments with and without inoculation of AMF, it was verified that the fungi promoted an increase of 50.3\% in mycorrhizal colonization, which justifies the greater root biomass (dry matter weight) in the treatments with inoculation. Thorne et al. (2013) also found no effect of mycorrhizal colonization on soil compaction, but observed $70 \%$ colonization in the treatments with AMF inoculation.

In soil inoculated with AMF, spore number ranged from 94 to 239 spores per $50 \mathrm{~mL}$ soil, which may explain the higher mycorrhizal colonization in the treatment with AMF. In the absence of AMF inoculation, smaller amounts of spores were present in the soil, varying from 5 to 71 per $\mathrm{mL}$, and there was also a reduction in the amount of spores with the increase in soil density (Figure 5).

The entry of organic carbon in the soil via phytomass, roots, and rhizodeposition can contribute to the mitigation of the erosive process in the soil. In this sense, arbuscular AMF can contribute to the increase in root dry matter in compacted soils, allowing decompression by improving the physical, chemical, and biological

Table 3. Summary of the variance analysis for mycorrhizal colonization and number of spores of arbuscular mycorrhizal fungi (AMF).

\begin{tabular}{lcc}
\hline Source of & \multicolumn{2}{c}{ Mean square } \\
\cline { 2 - 3 } variation $^{(1)}$ & Mycorrhizal colonization & Spore density \\
\hline Soil density (SD) & $36.32^{\text {ns }}$ & $4,257.44^{*}$ \\
AMF & $15,200.67^{* *}$ & $108,541.50^{* *}$ \\
SD x AMF & $418.00^{*}$ & $4,346.94 * *$ \\
\hline CV $(\%)$ & 11.24 & 23.25 \\
\hline
\end{tabular}

${ }^{(1)} \mathrm{CV}$, coefficient of variation. ** and *Significant at 1 and $5 \%$ probability,

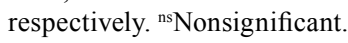

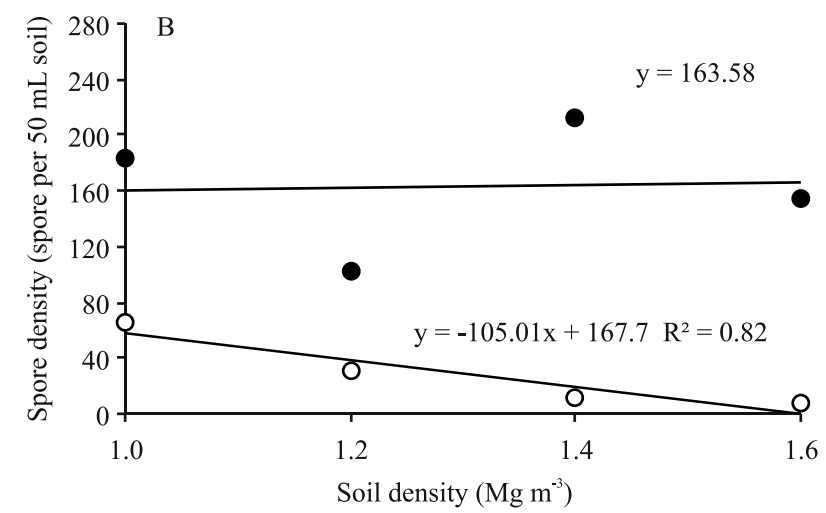

- With inoculation

Figure 5. Mycorrhizal colonization in Urochloa decumbens (A) and spore number of arbuscular mycorrhizal fungi (B) at different degrees of soil density. 
conditions of the soil, increasing the nutrient cycle and the efficiency of correctives and fertilizers.

\section{Conclusions}

1. The increase in soil density negatively affects the biomass accumulation and the macro- and micronutrient contents of Urochloa decumbens.

2. The inoculation of arbuscular mycorrhizal fungi influences root biomass accumulation and $\mathrm{N}$ and $\mathrm{Ca}$ contents of $U$. decumbens at different soil densities.

\section{Acknowledgments}

To Conselho Nacional de Desenvolvimento Cientifico e Tecnológico (CNPq), to Coordenação de Aperfeiçoamento de Pessoal de Nível Superior (Capes), and to Fundação de Amparo à Pesquisa de Minas Gerais (Fapemig), for support.

\section{References}

CABRAL, C.E.A; BOMFIM-SILVA, E.M.; BONELLI, E.A.; SILVA, T.J.A. da; CABRAL, C.H.A.; SCARAMUZZA, W.L.M.P. Compactação do solo e macronutrientes primários na Brachiaria brizantha cv. Piatã e Panicum maximum cv. Mombaça. Revista Brasileira de Engenharia Agrícola e Ambiental, v.16, p.362367, 2012. DOI: 10.1590/S1415-43662012000400005.

CARNEIRO, M.A.C.; SIQUEIRA, J.O.; CURI, N.; MOREIRA, F.M.S. Efeitos da inoculação de fungos micorrízicos arbusculares e da aplicação de fósforo no estabelecimento de forrageiras em solo degradado. Pesquisa Agropecuária Brasileira, v.34, p.16691677, 1999. DOI: 10.1590/S0100-204X1999000900018.

CARNEIRO, M.A.C.; SIQUEIRA, J.O.; DAVIDE, A.C. Fósforo e inoculação com fungos micorrízicos arbusculares no estabelecimento de mudas de embaúba (Cecropia pachystachya Trec). Pesquisa Agropecuária Tropical, v.34, p.119-125, 2004.

CASTAGNARA, D.D.; ZOZ, T.; CASTRO, A.M.C. e; ZOZ, A., OLIVEIRA, P.S.R. de. Crescimento de Stylosanthes cv. Campo Grande em diferentes níveis de densidade de um Latossolo Vermelho. Revista Ciência Agronômica, v.44, p.260-266, 2013. DOI: 10.1590/S1806-66902013000200007.

FARIAS, L. do N.; SILVA, E.M.-B.; PIETRO-SOUZA, W.; VILARINHO, M.K.C.; SILVA, T.J.A. da; GUIMARÃES, S.L. Características morfológicas e produtivas de feijão guandu anão cultivado em solo compactado. Revista Brasileira de Engenharia Agrícola e Ambiental, v.17, p.497-503, 2013. DOI: 10.1590/S1415-43662013000500005.

FERREIRA, D.F. Sisvar: a guide for its bootstrap procedures in multiple comparisons. Ciência \& Agrotecnologia, v.38, p.109112, 2014. DOI: 10.1590/S1413-70542014000200001.
GERDEMANN, J.W.; NICOLSON, T.H. Spores of mycorrhizal endogone species extracted from soil by wet sieving and decanting. Transactions of the British Mycological Society, v.46, p.235244, 1963. DOI: 10.1016/S0007-1536(63)80079-0.

GOMIDE, P.H.O; SANTOS, J.G.D. dos; SIQUEIRA, J.O.; SOARES, C.R.F.S. Diversidade e função de fungos micorrízicos arbusculares em sucessão de espécies hospedeiras. Pesquisa Agropecuária Brasileira, v.44, p.1483-1490, 2009. DOI: 10.1590/ S0100-204X2009001100016.

GRACE, C.; STRIBLEY, D.P. A safer procedure for routine staining of vesicular-arbuscular mycorrhizal fungi. Mycological Research, v.95, p.1160-1162, 1991. DOI: 10.1016/S09537562(09)80005-1.

KOSKE, R.E.; GEMMA, J.N. A modified procedure for staining roots to detect VA mycorrhizas. Mycological Research, v.92, p.486-488, 1989. DOI: 10.1016/S0953-7562(89)80195-9.

LIMA, L.B. de; PETTER, F.A.; LEANDRO, W.M. Desempenho de plantas de cobertura sob níveis de compactação em Latossolo Vermelho de Cerrado. Revista Brasileira de Engenharia Agrícola e Ambiental, v.19, p.1064-1071, 2015. DOI: 10.1590/1807-1929/agriambi.v19n11p1064-1071.

MACEDO, M.C.M.; ZIMMER, A.H.; KICHEL, A.N.; ALMEIDA, R.G. de; ARAUJO, A.R. de. Degradação de pastagens, alternativas de recuperação e renovação, e formas de mitigação. In: ENCONTRO DE ADUBAÇÃO DE PASTAGENS DA SCOT CONSULTORIA - TEC - FÉRTIL, 1., 2013, Ribeirão Preto, SP. Anais. Bebedouro: Scot Consultoria, 2013. p.158-181.

MALAVOLTA, E. Elemento de nutrição mineral de plantas. Piracicaba: Agronômica Ceres, 1980. 251p.

MALAVOLTA, E.; VITTI, G.C.; OLIVEIRA, S.A. de. Avaliação do estado nutricional das plantas: princípios e aplicações. 2.ed. Piracicaba: Potafos, 1997. 319p.

MEDEIROS, R.D. de; SOARES, A.A.; GUIMARÃES, R.M. Compactação do solo e manejo da água. I: Efeitos sobre a absorção de N, P, K, massa seca de raízes e parte aérea de plantas de arroz. Ciência e Agrotecnologia, v.29, p.940-947, 2005. DOI: 10.1590/ S1413-70542005000500004.

MIRANSARI, M.; BAHRAMI, H.A.; REJALI, F.; MALAKOUTI, M.J. Effects of arbuscular mycorrhiza, soil sterilization, and soil compaction on wheat (Triticum aestivum L.) nutrients uptake. Soil \& Tillage Research, v.104, p.48-55, 2009a. DOI: 10.1016/j. still.2008.11.006.

MIRANSARI, M.; BAHRAMI, H.A.; REJALI, F.; MALAKOUTI, M.J. Effects of soil compaction and arbuscular mycorrhiza on corn (Zea mays L.) nutrient uptake. Soil \& Tillage Research, v.103, p.282-290, 2009b. DOI: 10.1016/j.still.2008.10.015.

MIRANSARI, M.; BAHRAMI, H.A.; REJALI, F.; MALAKOUTI, M.J.; TORABI, H. Using arbuscular mycorrhiza to reduce the stressful effects of soil compaction on corn (Zea mays L.) growth. Soil Biology \& Biochemistry, v.39, p.2014-2026, 2007. DOI: 10.1016/j.soilbio.2007.02.017.

RIBEIRO, M.A.V.; NOVAIS, R.F.; FAQUIN, V.; FERREIRA, M.M.; FURTINI NETO, A.E.; LIMA, J.M. de; VILLANI, E.M. de A. Resposta da soja e do eucalipto ao aumento da densidade do 
solo e a doses de fósforo. Revista Brasileira de Ciência do Solo, v.34, p.1157-1164, 2010. DOI: 10.1590/S0100-06832010000400015.

SANTOS, H.G. dos; JACOMINE, P.K.T.; ANJOS, L.H.C. dos; OLIVEIRA, V.A. de; LUMBRERAS, J.F.; COELHO, M.R.; ALMEIDA, J.A. de; CUNHA, T.J.F.; OLIVEIRA, J.B. de. Sistema brasileiro de classificação de solos. 3.ed. Brasília: Embrapa, 2013. $353 \mathrm{p}$.

SOUZA, M.A.S.; FAQUIN, V.; SILVA, D.R.G.; OLIVEIRA, C. de; BASTOS, C.E.A. Acúmulo de macronutrientes na soja influenciado pelo cultivo prévio do capim-marandu, correção e compactação do solo. Revista Ciência Agronômica, v.43, p.611622, 2012. DOI: 10.1590/S1806-66902012000400001.

THORNE, M.; RHODES, L.; CARDINA, J. Soil compaction and arbuscular mycorrhizae affect seedling growth of three grasses.
Open Journal of Ecology, v.3, p.455-463, 2013. DOI: 10.4236/ oje.2013.37052.

TRESEDER, K.K.; TURNER, K.M.; MACK, M.C. Mycorrhizal responses to nitrogen fertilization in boreal ecosystems: potential consequences for soil carbon storage. Global Change Biology, v.13, p.78-88, 2007. DOI: 10.1111/j.1365-2486.2006.01279.x.

VALICHESKI, R.R.; GROSSKLAUS, F.; STÜRMER, S.L.K.; TRAMONTIN, A.L.; BAADE, E.S.A.S. Desenvolvimento de plantas de cobertura e produtividade da soja conforme atributos físicos em solo compactado. Revista Brasileira de Engenharia Agrícola e Ambiental, v.16, p.969-977, 2012. DOI: 10.1590/ S1415-43662012000900007.

$\overline{\text { Received on April 5, } 2017 \text { and accepted on October 5, } 2017}$ 